\title{
Влияние легирования матрицы ук621.763;59.422.5 на характер разрушения и прочность углеалюминиевого композита
}

\section{Matrix alloying influence on the failure character and strength of a carbon-aluminum composite}

\begin{abstract}
А. И. Гомзин, Н. Г. Зарипов, А. В. Боткин Уфимский государственный авиационный технический университет, Уфа, Россия
\end{abstract}

\section{Р. Ф. Галлямова}

Уфимский институт химии РАН, Уфа, Россия

\author{
A. I. Gomzin, N. G. Zaripov, A. V. Botkin \\ Ufa State Aviation Technical University, \\ Ufa, Russia \\ R. F. Gallyamova \\ Ufa Chemistry Institute of RAS, Ufa, Russia
}

поступила в редакцию 12.102020 , принята к печати 21.10.2020

\section{Абстракт}

Выбор сплава матрицы при изготовлении композитов с армированием углеродными волокнами является важным фактором, определяющим конечные свойства материала. В данной статье представлены результаты исследований однонаправленных углеалюминиевых композитов с матрицами из алюминия марки A7 и алюминиевого сплава марки АК12. Проведены механические испытания на трёхточечный изгиб и микроструктурные исследования поверхностей разрушения композитов и поверхностей углеродных волокон. Установлено, что кремний в составе алюминиевой матрицы снижает интенсивность химического взаимодействия с армирующими волокнами и способствует увеличению прочности при трёхточечном изгибе композитов, которая в данной работе была повышена с 288 до 413 МПа.

\section{Abstract}

The choice of matrix alloy in the composite fabrication with carbon fiber reinforcement is an important factor determining the final properties of the material. This article presents the results of a study of unidirectional carbon-aluminum composites with aluminum A7 and aluminum alloy AK12 matrices. Three-point bending tests and microstructural studies of the fracture surfaces of composites and carbon fiber surfaces were carried out. It was found that silicon in the aluminum matrix reduces the fibre/matrix chemical interaction. This yields an increase in the strength of the composites from 288 to $413 \mathrm{MPa}$.

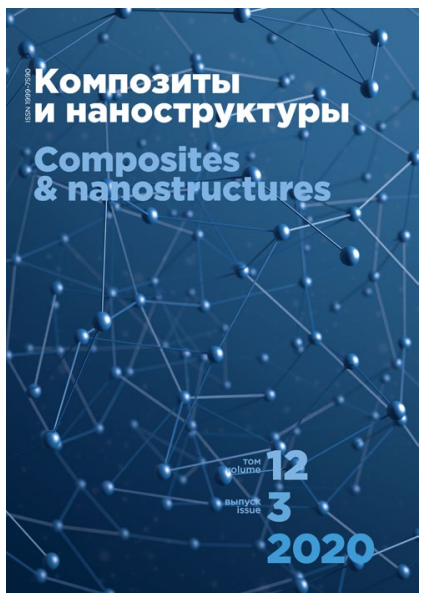

